\title{
NAS FRONTEIRAS DO ESTADO-NAÇÃO: CONFLITOS SOCIOAMBIENTAIS E INCÊNDIOS FLORESTAIS NAS TERRAS INDÍGENAS DOS AWÁ-GUAJÁ NO MARANHÃO
}

\author{
IN THE NATION-STATE BORDERS: \\ SOCIO-ENVIRONMENTAL CONFLICTS AND FOREST FIRES \\ ON AWÁ-GUAJÁ'S INDIGENOUS LANDS IN MARANHÃO
}

\author{
Eliane Cantarino O'Dwyer*
}

Os ventos da mudança soprados de fora das sociedades indígenas varreram a pré -amazônia maranhense com as frentes de expansão econômica e maior densidade populacional, pela facilidade de deslocamento através da construção de rodovias e uma ferrovia interestadual nas últimas três décadas. A estrada de ferro Carajás que, em 2014, apresenta projeto de duplicação, resultou em efeitos trágicos sobre o grupo indígena Awá e seus modos tradicionais de existência, isolados nas florestas e nascentes dos rios Pindaré, afluente Caru, Gurupi e Turiaçu e na área indígena Amarante.

Empurrados de seus territórios de caça e coleta, cercados por povoados e fazendas, muitas vezes impossibilitados de retornar para as regiões afastadas das serras que conheciam ou até sem capão de mato onde se esconder, os Awá tiveram que lutar pela sobrevivência individual ou em grupo. Ora perseguidos, fogem sós, desgarrados que foram dos familiares, e sem destino anos a fio, passam a "roubar" das lavouras e a "matar" animais de criação como os praticantes de delitos, submetendo-se sem saber a todos os riscos desta condição na sociedade em que desconhecem a língua, as regras e as leis. Ora sobreviventes, sem alternativa, assistem a morte gradativa dos parentes, pai, mãe, irmãos, esposo, esposa, filhos e os que restam se expõem às vistas dos brancos sempre por eles temidos, num ato de desespero que se mostrou por vezes

\footnotetext{
* Professora Titular do Departamento de Antropologia e do Programa de Pós-Graduação em Antropologia da Universidade Federal Fluminense - UFF (Niterói/RJ/Brasil), líder do Grupo de Estudos Amazônicos do Diretório de pesquisas do CNPq e membro do Conselho Científıco da Associação Brasileira de Antropologia.

E-mail: elianeantropologia@gmail.com
} 
eficaz pelos avisos sobre o aparecimento de indígenas, ao produzir comoção social e implementar programas de assistência e o reconhecimento oficial sobre a garantia de uma vida coletiva.

Deste modo, os limites administrativos que atualmente dividem os diversos grupos Awá contatados em quatro postos indígenas (Pin Awá na Terra Indígena Caru; Pin Tiracambu na Terra Indígena Caru; Pin Guajá na Terra Indígena Alto Turiaçu; Pin Juruti na Terra Indígena Awá, além da Terra Indígena Amarante), devem ser considerados como resultado de um processo que pode refletir decisões e ações tomadas intencionalmente no passado.

Os Awá, através da solidariedade do grupo de irmãos, organizam-se em um sistema social segmentar, sem instituições centralizadas, que se reproduzem em uma área ecologicamente homogênea da pré-amazônia brasileira. Os processos que ocorreram ao longo do tempo sustentaram o padrão de nomadismo que encontramos ainda hoje, através da ocupação dos contrafortes das serras do Tiracambu e da Desordem e, principalmente, das cabebeiras dos rios Gurupi, Pindaré, Turiaçu com seus afluentes e inúmeros igarapés. 0 grupo de irmãos parte para caçar junto com suas famílias e se deslocam pelo território de caça-coleta que reconhecem pelos marcos assinalados como determinada árvore, cursos de rio e suas ramificações, até sinais de galhos quebrados na mata. Os deslocamentos são necessários para perseguir a caça, e a alimentação é constituída por carne de caça, pelo mel silvestre e a farinha de babaçu. Os grupos contatados substituíram a farinha de babaçu pela mandioca, mas misturamlhe as amêndoas de babaçu. No caso dos Awá, o nomadismo não representa a busca ilimitada de florestas virgens atrás da caça.
A cobertura vegetal necessária à reprodução das espécies animais não prescinde da existência dos babaçuais ou as chamadas "capoeiras velhas" que resultam das atividades de horticultores indígenas, como os Urubus-Kaapor e Guajajara que compartilham com eles o território da antiga Floresta Nacional do Gurupi e participam desse conjunto interconectado de grupos étnicos e territórios tribais.

\section{Nomes de família, habitats e topônimos}

Na situação de trabalho de campo pericial realizado em 2000-2002 (processo judicial $n^{\circ}$ 95.353-8. 5a Vara da Justiça Federal do Maranhão) nas aldeias Awá, Tiracambu, Guajá e Juriti, respectivamente Terras Indígenas Caru, Alto Turiaçu e Awá, ao perguntarmos sobre os nomes das famílias residentes no posto indígena, os Awá entrevistados respondiam designando o nome dos territórios de caça-coleta por eles utilizados - os harakwas. Deste modo, os nomes de família eram identificados como nomes de habitats, alguns antigos que precisaram abandonar pela pressão das frentes de expansão, outros constituíam novas áreas utilizadas para as atividades de subsistência em condições de reserva indígena. Essa "designação das unidades de parentesco por topônimos correspondentes a locais de residência" constitui uma prática recorrente no caso de outros povos tribais, como os Kanak da Nova Caledônia. (BENSA, 1998, p. 56)

0 levantamento do estoque de topônimos por meio dos quais os Awá, nos diversos postos indígenas, designam os lugares de caça-coleta, inclusive aqueles em que viviam anteriormente às condições de reserva indígena, permite decifrar a combinação que fazem entre as localidades atuais e os habitats que deixaram desocupados para trás. 
Apesar dos povos amazônicos serem, a princípio, considerados a-históricos, o interesse dos Awá pela história pessoal e do seu grupo encontra-se diretamente relacionado à passagem de uma forma de vida indígena isolada ao envolvimento maior com as frentes de expansão econômica e o Estado nacional. Neste caso, o passado concebido como modelo atemporal que se expressa no mito de Maíra sobre a criação do mundo, comum em sua versão à cosmologia dos seus vizinhos Urubu-Kaapor (RIBEIR0, 1996, p. 444-447), é igualmente relacionado a um tempo histórico marcado pelos eventos do contato interétnico. 0 modo próprio de organizar e exprimir sua historicidade é relacionado ao estoque de topônimos atribuídos aos seus harakwas, ao remontar a cadeia de lugares onde residiram eles próprios e seus antepassados. Nos postos indígenas Awá, Tiracambu, Guajá e Juriti, que reúnem os grupos Awá contatados, os harakwas são relacionados ao lugar de origem e a ocupação de diferentes habitats podem remeter a um contexto espacial muito mais extenso.

As atividades de caça realizadas por um grupo em seu harakwa não significam que percorram em conjunto todo esse território. Os trechos de floresta do harakwa são utilizados pelas diferentes unidades familiares do grupo em seus deslocamentos. As caçadas obedecem ao ciclo próprio de reprodução dos animais, como macacos, paca, anta, veados, porcão (tiahu) etc. Quando abatem uma fêmea com filhotes, recolhemno e entregam a uma das mulheres do grupo, que pode assumir o papel de provedora. Ela passa a cuidar do filhote e o tipo de laço criado na domesticação dos animais tem se manifestado como afetivamente forte. Quando crescem e entram na fase reprodutiva, os animais são levados para as áreas distantes dos seus harakwas para evitar que matem e se alimentem dessa criação. Pela combinação das esferas de caça e domesticação de animais silvestres, os Awá integram-se como elemento humano nesse ecossistema da pré-amazônia maranhense.

0 aldeamento nos postos indígenas e a reunião de uma população muito maior do que os grupos isolados que mantêm em média vinte a trinta pessoas, quando não estão pressionados, só é viável através da agricultura, principalmente o plantio da mandioca e fabrico da farinha, que garante a concentração recorde de uma população de cento e seis pessoas no Pin Awá, área indígena Caru, segundo dados populacionais compulsados no período do laudo antropológico realizado em 2000-2002. 0 modo atual de viverem concentrados no aldeamento do posto indígena, onde constroem seus haipa, isto é suas habitações, tem sido associado por eles mediante a acumulação de pessoas e de uma série de habitações num mesmo local, após o contato interétnico, a uma colmeia de abelhas - hairohú - de que são especialistas em retirar o mel.

Sobre a área agricultável e a produção de farinha, encontram-se diretamente relacionadas ao número de pessoas e ao tempo de permanência na mata programado para as atividades de caça-coleta que pode durar alguns meses. A alternância entre sedentarização e nomadismo encontra-se relacionada à sazonalidade agrícola e aos períodos mais afeitos às atividades de caça-coleta de determinada espécie animal ou vegetal. De acordo com um servidor da Fundação Nacional do Índio (FUNAI): "passam às vezes seis meses vivendo do modo como sempre fizeram, quando voltam a vida nômade deles na mata”.

0 movimento contínuo dos grupos em seus harakwas e o entrecruzamento das rotas na área montanhosa pode ser pensado 
em termos de fluxos produzidos no espaço em várias direções, a imagem e semelhança dos seus rios caudalosos, mas também de estreitos riachos e igarapés, tanto correntezas isoladas como confluências. Este fluxo de grupos Awá em movimento, como também de significados culturais compartilhados, foi cortado por descontinuidades e obstáculos produzidos fora das comunidades indígenas que partilhavam o território da antiga Reserva Florestal do Gurupi.

As separações forçadas, a perda de antigos harakwas e as pressões constantes ao longo das fronteiras do território Awá, com a imobilização de antigos fluxos e a impossibilidade para os grupos contatados, principalmente os que ficaram no Alto Turiaçu de atravessar as cabeceiras de rios e cadeias montanhosas como faziam anteriormente, tiveram consequências dramáticas que se revelam através das experiências e trajetórias de vida de homens e mulheres desse povo indígena.

A forma essencialmente dramática dos relatos, ouvidos no trabalho de campo pericial sobre separações e mortes no passado de suas vidas, representa pelo que pudemos verificar sequências de eventos que acarretam mudanças ao longo do tempo nas formas de organização do espaço antes ocupado e suas interações baseadas em laços de consanguinidade e alianças pelo casamento. Sobre as separações forçadas, como verificamos através dos relatos, os sobreviventes em fuga não perdem sua identidade étnica e são acolhidos em outro grupo Awá, onde obtêm proteção e se incorporam, como no caso da índia Merakedja, atualmente já falecida e que residia na aldeia Awá, na terra indígena Caru. Outros sobreviventes encontrados em povoados camponeses foram entregues à FUNAI e reincorporados aos grupos contatados nas reser- vas indígenas, como Geï Guajá que, ainda criança, viveu na reserva do Alto Turiaçu e atua como intérprete nos quadros do órgão indigenista. Os relatos feitos por diferentes informantes nativos em ocasiões diversas e os comentários de outros participantes nos postos indígenas Guajá, Awá, Tiracambu e Juriti, permitem evidenciar, pelas operações comparativas envolvidas, as formas de pertencimento cruzado e interconexões entre grupos ao longo de uma fronteira étnica e territorial, em que se viram dispersos pelos ataques de caçadores e invasores dessa área de antiga Reserva Florestal.

\section{Genocídio Doméstico?}

Na definição do genocídio doméstico, têm sido considerados os atos cometidos com a intenção de destruir, no todo ou em parte, grupos étnicos, raciais ou religiosos, incluindo formas de genocídio cultural. Nos tipos de genocídio doméstico se encontra aquele praticado contra povos indígenas. Esta é uma forma contemporânea dos massacres do período colonial, atualmente perpetrada contra pequenos grupos de caçadores e coletores ameaçados de extinção, vítimas de uma economia de desenvolvimento predatório (KUPER, 1982, p. 216), como no caso do povo indígena Awá-Guajá que habita a antiga área da reserva florestal do Gurupi, na pré-amazônia maranhense.

Diante de uma situação de ameaças e ataques, como no caso dos Awá residentes no posto Juriti, resistem às invasões e constrangimentos extralegais. Segundo informações levantadas no trabalho de campo realizado em dezembro de 2005, a partir de depoimentos dos próprios Awá do Pin Juriti e servidores da FUNAI, no harakwa do Água Preta, existe uma invasão de quinhentas pessoas, representadas por José Otávio, 
gerente dos interesses latifundiários dos Galetti, residentes no município de Imperatriz, que tem delimitado e vendido lotes dentro da área indígena Awá. Há muitos roçados nessa área, sendo que os conflitos agravaram-se após a demarcação da área, em 2002, pela FUNAI, que aguarda uma decisão judicial para desintrusão da reserva indígena. Além de ameaçarem índios e servidores do órgão indigenista, divulgam em reuniões políticas de uma cooperativa para distribuição de terras, formada em São João do Caru, que o objetivo deles é reduzir a área demarcada pela FUNAI ao igarapé Água Preta, distante apenas 7,5 km do posto indígena.

Sobre a ameaça atual de redução drástica desse território de caça e coleta, podese considerar que o fechamento da fronteira norte-sul da área Awá, que impede a reprodução dos fluxos territoriais e as interconexões entre os diferentes segmentos desse grupo indígena ao longo de uma fronteira étnica e territorial, pode repercutir no fracasso de manter sua identidade e na alternativa sempre aberta de assimilação, ao norte pelos urubu-kaapor e ao sul pelos guajajara. Tal fracasso em garantir a adequada proteção para o povo Awá prover sua subsistência através de seus tradicionais meios de caça e coleta, pode igualmente representar uma transformação radical da cultura Awá e da relevância organizacional que ela assume para um dos últimos povos considerados coletores-caçadores das terras baixas da América do Sul.

\section{0 fazer antropológico}

A prática etnográfica, ao mostrar-se "atenta ao encadeamento das situações concretas”, pode ser "capaz de revelar (...) os processos por meio dos quais os acontecimentos são construídos, e seus ecos na vida social conservados ou alterados, (e assim) desvendados em toda sua diacronia" (BENSA, 1998, p. 52). Do mesmo modo,

para Bateson (1977, op. cit. BENSA, 1998) as relações entre os fatos observados e os diferentes contextos dos quais eles dependem devem ser antes entendidos como processos. 0 contexto é imanente às práticas, faz parte delas. É portanto impossível pensá-lo em termos de estrutura estática (BENSA, 1998, p. 46).

Seguindo essa perspectiva metodológica, desenvolvemos a análise dos múltiplos contextos dos trabalhos de campo realizados na área indígena Awá, como no caso a seguir.

No âmbito do projeto Politicas para a Diversidade e os Novos Sujeitos de Direitos: estudos antropológicos das práticas, gêneros textuais e organizações de governo, desenvolvido mediante convênio FINEP/Ministério da Ciência e Tecnologia ${ }^{1}$, realizamos visita breve à Área Indígena (AI) Awá entre os dias 23 e 27 de novembro de 2007. Esta viagem a campo foi precedida por outras situações anteriores de pesquisa etnográfica, como no caso da perícia antropológica realizada entre os anos de 2000-2003 (Processo

1. 0 referido projeto é desenvolvido no Laboratório de Pesquisa em Etnicidade, Cultura e Desenvolvimento (LACED), vinculado ao Departamento de Antropologia do Museu Nacional da Universidade Federal do Rio de Janeiro (MN/UFRJ), sob a coordenação do Dr. Antonio Carlos Souza Lima e co-coordenado pela Dra. Adriana de Resende Barreto Vianna e pela Dra. Eliane Cantarino 0’Dwyer do Departamento de Antropologia e Programa de Pós-graduação em Antropologia da Universidade Federal Fluminense (PPGA/ UFF), com financiamento do convênio FINEP n. 01.06.0740.00 - REF : 2173/06 - Processo FUJB n. 12.867-8, com recursos do Fundo Nacional de Desenvolvimento Científico e Tecnológico (FNDCT)/Ministério de Ciência e Tecnologia. 
Judicial $n^{\circ}$ 95.353-8 da 5a Vara da Justiça Federal do Maranhão), e posteriormente integrando a equipe do projeto Etnoarqueologia dos Awá-Guajá ${ }^{2}$, quando foram efetuadas visitas breves e repetidas, seguindo a tradição norte-americana da etnologia nas reservas (CLIFFORD, 1999, p. 79, 117), respectivamente, em novembro de 2005 e novembro de 2006, ano no qual iniciamos nossas atividades de pesquisa com apoio do Fundo Nacional de Desenvolvimento Científico e Tecnológico do Ministério da Ciência e Tecnologia (FNDCT/MCT).

Nessa viagem de campo ao Posto Indígena Juriti (AI Awá), onde se encontram os últimos grupos Awá, antes isolados nas matas, que foram contatados em 1986 e 1992, respectivamente, no igarapé Juriti, e nas proximidades dos igarapés Mutum e Água Preta, o deslocamento foi feito num veículo da FUNAI, do Serviço de Apoio de Santa Inês (SASI). A partir do município de São João do Caru, trafegamos por estrada de rodagem, que atravessa a AI Awá, ao longo do igarapé Água Preta na direção do igarapé Araçatiwa, já na divisa com a Reserva Biológica do Gurupi, sendo que algumas variantes dessa estrada, abertas pelos madeireiros, foram percorridas por uma operação da Polícia Federal em meados de 2006.

Durante a viagem, registramos grande desmatamento numa área de floresta recém queimada e reduzida a cinzas, situação que se repete sistematicamente ao longo da estrada. A extração de madeira, com a derrubada e a queima da cobertura vegetal, cria áreas de clareiras onde são plantados roçados de mandioca e arroz por pequenos agricultores regionais, que ajudam no trabalho de derrubada da madeira a ser comercializada e na maioria das vezes substitui, após a colheita, as lavouras pelo plantio de capim que dão lugar a fazendas agropecuárias. Esta prática tem exceções, como no caso dos agricultores familiares que possuem lotes fora da área de reserva indígena, sendo inclusive observada no percurso da viagem uma área preservada, que dizem pertencer a um líder comunitário chamado Talioca, o qual não permite desmatamento nessa pequena reserva florestal para fins extrativistas. Mais adiante, já dentro dos limites da área indígena Awá, atravessamos o Povoado do Caju, onde a prefeitura de São João do Caru construiu uma escola. No nosso retorno a São João do Caru, na localidade de Nova Olinda, passamos por um caminhão em sentido contrário, que estava carregado com tábuas de madeira de lei, maçaranduba, já beneficiadas pelo uso da serra elétrica.

Deste modo, o avanço da frente de expansão madeireira e agropecuária sobre a reserva indígena Awá, com a diminuição drástica da área de 118 mil ha demarcada pela FUNAI, reduz na prática o território utilizado pelos Awá para atividades de caça e coleta, independentemente da ação judi-

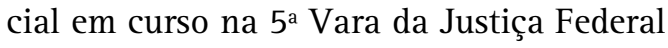
do Maranhão, nesse ano de 2007, conclusa para sentença. Segundo informações dos servidores do posto indígena e da população regional, em 2004, o então prefeito de São João do Caru disse em programa de rádio local que a AI Awá ia ser alterada para o limite do Água Preta e que a população poderia morar e fazer suas roças dentro da reserva. Assim, políticos locais, conforme

2. Projeto: Etnoarqueologia dos Awá (Guajá). Pesquisadora Responsável: Dra. Almudena Hernando Gonzalo - Departamento de Pré-História da Universidade Complutense de Madrid. Pesquisadora colaboradora: Dra. Eliane Cantarino 0’Dwyer - Departamento de Antropologia/PPGA/UFF. 
disseram os informantes, incentivam colonos do povoado de Santarém e outras localidades de São João do Caru, e dos municípios de Zé Doca e Bom Jardim, “a invadir a reserva indígena”. Nem as contestações judiciais e manifestações anteriores a favor e contrárias aos acréscimos e diminuições da AI Awá, até a Portaria Ministerial no 373 de 27.07.1992, alcançaram tal efeito restritivo à reprodução do modo de vida e as práticas culturais dos Awá.

O harakwa - território de caça e coleta - do Água Preta, com suas margens invadidas pelos karai, como chamam os homens brancos em tupi, não pode mais ser utilizado pelos Awá do Pin Juriti, só sendo possível perambular atualmente na direção do igarapé Mutum, ao sul da AI Awá no limite com a AI Caru, onde vivem os Guajajara e estão situados dois postos indígenas da frente de atração dos Awá-Guajá, os Pin Awá e Tiracambu. 0 chefe do posto indígena Juriti acredita que é nessa direção que devem se encontrar ainda alguns poucos grupos Awá, isolados na mata, que foram casualmente vistos há cerca de dois anos por Wyroho, que segundo seu relato confundiram-no com um karaí pelo calção que trajava e só o largaram quando se comunicou com eles na mesma língua e saíram juntos em direção a um acampamento onde ouvira vozes e conseguiu fugir em disparada pela mata de volta ao posto indígena. De acordo com suas palavras, esses Awá da mata falavam com um sotaque muito rápido e ao segurarem-no com força pelo braço, disseram para segui-los porque o acharam muito triste. A expressão desse sentimento atribuído à observação sobre ele feita por outro Awá, ainda indio brabo, conforme a classificação dos servidores do posto indígena assumida por ele próprio, pode representar a autoatribuição de um sentimento de perda e dor na nova vida a que foram obrigados a se habituar nas condições de confinamento nos postos indígenas.

Os Awá do Pin Juriti foram em parte transformados em agricultores, pelo disciplinamento de uma prática segundo as diretrizes do posto indígena, que contrata alguns lavradores entre os regionais para desenvolver o cultivo e conta com a participação praticamente integral dos homens jovens adultos Awá, que são assim subtraídos das atividades de caça e coleta, realizadas nesse mesmo período do verão quando se derruba as capoeiras e/ou a mata para o plantio do roçado. Só os mais velhos, as mulheres, as crianças e alguns que não puderam ser disciplinados mantêm-se afastados das atividades agrícolas, confinados, contudo, a pequenas caçadas perto do posto, e sem contar com os jovens adultos, imprescindíveis para os deslocamentos maiores em direção aos harakwas - território de caça e coleta - dos igarapés Mutum e Água Preta, esse último recentemente invadido, usados tradicionalmente pelo grupo inclusive para as atividades de coleta de palmeira para cobertura dos haipa (habitação), de coco babaçu, usado como comestível e folhas de tucum, sendo esta última atividade exclusivamente feminina visando a confecção do vestuário e de redes.

\subsection{Situação de Perda}

Nas condições anteriores de trabalho de campo, realizado em novembro de 2006, um trágico episódio, recém ocorrido naquela ocasião, se impôs como tema de nossas conversas por iniciativa dos próprios índios. A morte de To'o, residente no PIN Juriti, representou um drama social que reproduz as situações de perda e separações forçadas que se somam à série ante- 
rior de incidentes ocorridos com este povo indigena (0'DWYER, 2001, p. 100-101). A liminaridade dessa experiência pessoal e coletiva encontra-se incorporada nos eventos trágicos que fazem parte da história de cada grupo Awá e da trajetória de todo índio identificado pela situação de contato. Assim, a dimensão trágica desses acontecimentos é revivida e atualizada por este caso dramático da morte de To'o, o qual integrando uma equipe da FUNAI se preparava para contatar grupos Awá isolados vivendo na proximidade da Área Indígena Araribóia, Maranhão.

Os Awá do Pin Juriti manifestaram-se com pesar sobre a trágica perda aos pesquisadores em visita ao posto indígena com palavras e gestos de desalento. Tal fato pode ser em princípio objeto de estranhamento na medida em que é praticamente "normativo" para os Awá "esquecer o nome dos mortos" (CORMIER, 2005, p. 6), "não sendo eles capazes de relembrar nomes da segunda geração ascendente" (CORMIER, 2003, p. 75). 0 processo de "amnésia genealógica" fora por eles expresso nas condições de trabalho de campo ao manifestarem dor e desgosto, ao mesmo tempo em que diziam para esposa de To'o e filhos, que deveriam superar a perda, esquecer aos poucos o passamento e voltar a casar, caçar e criar seus filhos.

No Pin Juriti realizaram o ritual da $\mathrm{Ka}$ ruara na segunda noite que passamos no posto indígena, em 24/11/2007. Os cânticos e a dança se iniciaram por volta das 21 horas e 30 minutos e às 3 horas da manhã ainda ouvíamos o canto agudo de mulheres e jovens. No cair da tarde haviam nos pedido para mostrar o vídeo da viagem a campo no período da perícia antropológica, no qual To'o aparece algumas vezes durante as entrevistas. Na dança ritual entram em contato com os parentes falecidos que acredi- tam viver no céu - o iwapi dos Awá. Para o ritual constroem uma tacaia no terreiro da aldeia, uma casa de palha toda fechada onde os homens entram para a "viagem ao céu" e voltam incorporados aos espíritos dos antepassados mortos. As mulheres fazem um círculo e ajudam a invocar os espíritos que através dos homens realizam consultas com fins de cura e propiciação de potências sobrenaturais e procedem a cura mediante sopro e sucção, especialidade de todos os homens adultos Awá. Para a dança da Karuara enfeitam-se com penas de tucano coladas ao corpo e de urubu-rei nas pernas para propiciar a "viagem ao céu". Ainda por ocasião do ritual da Karuara, costumam fazer uso da planta medicinal ka'akaçu'u, classificada como analgésico e antitérmico, que além dos borrifamentos medicinais, serve igualmente como "repelente de fantasma aiyã (...) que podem funcionar, em certo sentido, para afastar memórias e lidar com a dor da perda”. Deste modo, o contexto etnográfico de realização da Karuara pode ter funcionado como um "mecanismo de obliteração da memória (...) e do sofrimento, considerado um estado de espírito tão devastador que é preciso tomar medida para evitar esse mal (CORMIER, 2005, p. 1).

0 ritual da Karuara costuma igualmente preceder as caçadas em noites de lua cheia, pois acreditam favorecer espiritualmente o grupo contra malefícios de toda ordem, como doença, acidente, falta de sorte ou ficar "panema”. Naquela noite no PIN Juriti a lua cheia em tom avermelhado e a dança ritual parecia anunciar a véspera de uma caçada de anta, veado, porcão e macaco na floresta. Contudo, no dia seguinte eram os meninos acompanhados das mulheres que trouxeram três cotias para aldeia e pescaram no arpão um surubim grande e outros peixes. Os homens jovens adultos estavam 
no roçado e nisso verifıcamos que também se paga um preço, expresso pela indignação de três jovens mães quando perguntadas sobre as vestimentas tradicionais, a saia de tucum e a tipóia na qual costumam carregar os seus bebês, confeccionada com o mesmo material, atualmente feitas de pano, ao mencionar a queima das palmeiras situadas próximo a aldeia, em virtude da derrubada de áreas para roçado de subsistência das famílias Awá. Sobre a roupas feitas de tucum disseram-nos que "ninguém tem mais, é muito longe de buscar” e só elas mulheres podem coletar. $\mathrm{Na}$ atividade tradicional de caça e coleta na floresta elas costumam acompanhar seus maridos juntamente com os filhos e nessas ocasiões se dedicam à coleta das palhas de tucum usadas para confecção tradicional de roupas e redes. Atualmente, desde 2002, só a velha Ameritxia é vista com saia de tucum, segundo a vestimenta tradicional.

\subsection{Disciplinamento das práticas culturais e alternativas à extinção}

No diário de campo escrito em 2007, encontra-se o seguinte registro etnográfico: com roupas de camponês, calça, botas, camisa, chapéu e facão na cintura, oferecidos pelo posto indígena, Pirahimahá, na beira do roçado de onde saíra para tomar água, sujo de fuligem, disse-nos que na véspera ouvira o barulho de moto-serra na direção do Água Preta e três paus (árvores) caindo. E se dirigindo a mim: "cheio de caboclo aí na mata, Dra. Eliane. Quero matar um de flecha, de flecha matar, esperar muito a Polícia Federal". Os servidores do posto aconselharam-no a aguardar a ação das autoridades competentes e explicaram-me que a operação de fiscalização nessa época do ano não evita a broca e derrubada da mata, que se inicia em junho, mas pode impedir o plantio e obrigar a retirada dos invasores que se encontram a $7,5 \mathrm{~km}$ da aldeia.

Nesse contexto, Pirahimahá, igualmente, se queixou ao chefe de posto, na minha presença, de fortes dores nas pernas e nas costas, pelas quais soube que ele precisou ser atendido por um médico em Santa Inês. Disse ele, ainda, que Wyroho não conseguira trabalhar no roçado, por queixar-se igualmente de dores, prestando assim conta dessa ausência ao chefe de posto, curiosamente num domingo, dia de folga semanal, que essa nova mão de obra indígena sujeita aos trabalhos agrícolas não consegue reconhecer ainda. Os índios queixam-se muito do enfermeiro do posto porque solicitam remédio para dor e não são atendidos, sendo-lhes dito que procurem os remédios do mato, os quais sempre fizeram uso. Contudo, recorrer ao remédio dos brancos como uma cura dos males causados por uma atividade física por eles desconhecida até a situação de contato pode ser relacionado às disposições corporais próprias para as atividades de caça, esgueirando-se na mata, e na coleta de produtos vegetais. Assim, não suportam, sem sofrimento físico, o disciplinamento forçado a outras práticas corporais relacionadas ao trabalho de derrubada e queima da mata para o plantio de roçados, o que exige igualmente um novo disciplinamento dos corpos.

Deste modo, a demarcação da área indígena Awá segundo os limites da Portaria Ministerial $n^{\circ} 373$ de 27.07.92 e a garantia de uma fronteira étnica e geográfica relativamente estável com a retirada dos invasores e a vigilância constante da área pode resultar em um movimento desses grupos através da fronteira norte-sul que leve a reconstituição de antigas trocas, inclusive matrimoniais entre aqueles que se encon- 
tram nos quatro postos indígenas Juriti, Awá,Tiracambu e Guajá e deles com os ainda (possivelmente) isolados nos contrafortes das serras da Desordem e Tiracambu.

Em 30 de junho de 2009, o Juiz Federal José Carlos do Vale Madeira proferiu sentença favorável a demarcação da Área Indígena Awá-Guajá, de acordo com os termos da Portaria n. 373/92 e o Laudo Antropológico produzido nos autos do Processo n. 95.0000353-8 no qual atuei como perita.

Segundo recomendação do antropólogo Ballé sobre povos caçadores-coletores como os Awá:

este estilo de vida não poderia continuar sem a continuação das áreas de cocais, como os babaçuais, isto é, sem a proteção das mesmas. Tal politica seria altamente coerente com os esforços contra a extinção de espécies vegetais também, pois várias espécies que ocorrem nas capoeiras velhas são exclusivas a este tipo de floresta, e são raras (BALLÉ, 1992).

Além disso, o reflorestamento de algumas dessas áreas em que ocorre intrusão na reserva indígena Awá pode assegurar a preservação de várias espécies animais, como os macacos, utilizados como caça e animal domesticado morando com as famílias em seus haipa (habitação). Assim, “a preservação das reservas indígenas (igualmente) provêm um refúgio para as espécies" (CORMIER, 2003, p. 38), tanto vegetais, como animais, e na reprodução de um padrão de nomadismo que implica no próprio uso e destinação sustentável dos recursos ambientais considerados necessários ao seu bem estar e à sua reprodução física e cultural, segundo seus usos, costumes e tradições - como conceitua a Constituição Federal do Brasil sobre as terras tradicionalmente ocupadas pelos índios.
Passada praticamente uma década do informe etnográfico que relata a invasão madeireira e a ameaça de genocídio do povo Awá e da decisão do juiz federal, em 2009, de demarcação e desintrusão da área indígena Awá, incêndios florestais de grande extensão assolaram diversas terras indígenas do Maranhão, afetando igualmente de modo dramático a terra indígena Awá.

Os incêndios florestais de grandes proporções que atingiram as terras indígenas do Maranhão, amplamente noticiados pela mídia no período de setembro de 2015 à abril de 2016, e tratados ora como parte das catástrofes naturais ora como intencionalmente provocados por interesses extrativistas madereiros, atingiram remanescentes de floresta amazônica e cerrado em territórios de ocupação tradicional reconhecidos e demarcados pelo Estado brasileiro, Terras Indígenas (TI) Araribóia, Geralda do Toco Preto, Cana Brava Guajajara, Governador, Krikati, Lagoa Comprida, Bacurizinho, Urucu, Juruá, Porquinhos, Canela e as TIs Alto Turiaçu, Awa e Caru, que formam o complexo Alto Turiaçu.

O sinistro provocado intencionalmente ou resultado de condições naturais, como por vezes noticiado, mobilizou sentimentos morais ao incidir sobre áreas de ocupação tradicional, com graves repercussões nos modos de fazer, criar e viver de diversos grupos indígenas, inclusive os Awá-Guajá, como já dissemos acima, considerados os últimos povos coletores e caçadores das terras baixas da América do Sul.

É a partir da minha experiência etnográfica de testemunhar os incêndios florestais na Terra Indígena Awá, em novembro de 2015, e no "Informe Etnográfico sobre a atual situação de ocupação da Terra Indígena Awá” escrito nessa mesma ocasião para o Ministério Público Federal, e no 
qual procuro traduzir os fatos observados e os significados produzidos pelos atores sociais, que desenvolvo o trecho a seguir, focalizando os incêndios florestais como resultado de intenções e ações humanas de agentes econômicos, políticos e do Estado na gestão do território e da própria catástrofe, com o objetivo não só de assumir a imparcialidade do observador, mas como uma questão de fazer história ao intervir no presente.

\section{Informe etnográfico sobre a atual situa- ção de ocupação da Terra Indígena Awá}

No relatório circunstanciado sobre a diligência a Terra Indigena Awá, segundo incumbência atribuída pelo Ministério Público Federal, focalizo, por meio de pesquisa, duas fontes de avaliação sobre o estado de coisas tais como verificado naquele universo socioambiental: minha observação direta e as informações coligidas e comentários significativos dos atores sociais. Ambos resultam em documentos reunidos durante o trabalho de campo através de anotações, gravações em áudio dos relatos e fotografias, dados esses textualizados nesse relatório que, comparativamente às experiências de pesquisa anteriores junto a esse grupo indígena (2000-2007), permitem descrever os fatos vividos em campo e trazer uma compreensão sobre o estado atual dessa situação etnográfica.

Do mesmo modo, desenvolvo um pensamento crítico sobre essa situação social ao me situar a partir dos acontecimentos vividos por ocasião da viagem até a aldeia Juriti (15 a 19 de novembro de 2015) e descrever a destruição imposta pelo fogo como uma forma de denúncia sobre a ordem social observada. Além disso, procuro, através da interlocução com agentes do campo indigenista e relatos dos Awá, explorar a experiência e reflexividade dos atores naquele contexto ao traduzir o que sabem sem renunciar à autonomia analítica do trabalho disciplinar da antropologia.

\subsection{A denunciação: Terra Indígena Awá arde em chamas}

Em 16 de novembro de 2015, a situação era gravíssima. Ao me deslocar de quadriciclo da Base Sul da FUNAI, próxima a cidade de São João do Caru, até o posto indígena e aldeia Juriti, atravessei áreas inteiramente calcinadas com partes ardendo em chamas. No trecho do antigo povoado do Caju, a vegetação florestal estava praticamente destruída. No caminho, árvores caídas obstruiam a passagem reaberta com motosserra; outras árvores, consumidas pelas labaredas, provocaram o sobrevoo em fuga de um gavião e a revoada de duas araras azuis em grasnido do topo de uma imensa sapucaieira, justo nesse período de ninhagem. Adiante, onde o fogo fazia uma trégua, encontrei um grupo formado por homens, mulheres e crianças Awá, ao todo uns dez, que acompanhavam Wyrohó a uma área para colher mandioca e fazer farinha há oito quilômetros da aldeia. Eles disseram ter encontrado animais como tatu, mambira, paca, jabuti e cobras consumidos pelo fogo. Os últimos cinco quilômetros percorridos até o posto da FUNAI, onde corta o igarapé Água Preta, ainda estavam a salvo das chamas.

$\mathrm{Na}$ aldeia Juriti, estive com Pirahima'a que, junto com Kiripi, comentou comigo, que após a desintrusão da área, os Awá passaram a se deslocar livremente além do igarapé Água Preta, mas mostrou-se preocupado com o destino daqueles que estão isolados. Esses Awá passaram a se aproxi- 
mar da parte sul do território após a retirada dos invasores, deixando vestígios como um matã (catitu) de estimação identificado pelo uso de uma coleira de tucum, o que assinalava a presença de Awá mihua (isolado/brabo), sendo vistas duas mulheres em correria com crianças chorando dentro da mata. A hipótese é desse grupo ter se refugiado novamente nos contrafortes da Serra da Desordem, o que aumenta a preocupação dos Awá da aldeia Juriti com o destino desses parentes, uma vez que se avista ao longe durante a noite o clarão do fogo no relevo das encostas.

Esse incêndio que se configura num desastre ambiental de grandes proporções, atingindo áreas de floresta e capoeiras em processo de crescente recuperação, após homologação e desintrusão da Terra Indígena Awá, abate-se igualmente sobre diversas espécies de mamíferos, tais como paca, cutia, tatu, anta, capivara, veado e manadas de porcões nunca antes observados tão próximos a aldeia Juriti pelos Awá.

A destruição a olhos vistos da cobertura vegetal durante todo deslocamento a Base Sul da Frente de Proteção Etnoambiental até a aldeia Juriti, com trechos de muita fuligem e altas temperaturas, indicam um incêndio de origem criminosa perpetrado pela ação de madeireiros e antigos invasores que voltaram a fazer queimadas para formação de pastos no interior da Terra Indígena Awá.

Segundo informações de campo, nos dias 10, 11 e 12 do corrente, nas imediações de Maranata e Pedrosa, que fazem divisa com a área indígena, um contingente do Batalhão de Polícia Florestal que se deslocava da área indígena Araribóia, prendeu cinco madeireiros com armas, motos e motosserras, mas sentiram-se impotentes em prosseguir a operação diante do grande número de invasores e destruição pelo fogo na área.

Esse relato de campo, escrito durante minha estada no posto indígena Juriti sobre os incidentes verificados no território de ocupação tradicional do povo indígena Awá-Guajá, será seguido das informações coligidas na interlocução com agentes do campo indigenista e relatos dos Awá.

Desse modo, se a revoada dos pássaros, o estalar da mata e o calor produzidos pelo fogo não significa que a natureza possa se comunicar conosco, já que só os humanos podem de fato responder aos sons da natureza e expressar seus sentimentos, inclusive de horror pelo dano ambiental produzido, “o silêncio da natureza significa que, não importa quanto barulho ela faça, ela não se envolve nas conversas que nós estabelecemos" (STEIL, 2012, p. 36) e só os interlocutores humanos presentes na situação etnográfica podem comparar e compartilhar suas percepções sobre tão trágica ocorrência.

\subsection{Diálogos em campo}

A opinião corrente é de que os invasores da terra indígena Awá são "capazes de tudo”. A invasão na parte norte e central da terra indígena se dá a partir de duas estradas que saem das sedes municipais de São João do Caru e Zé Doca e atravessam toda área até se encontrarem no "estreito" da terra indígena que faz divisa com Maranata e Pedrosa. Dali, juntam-se em uma única estrada em direção a Paragominas, no Pará. Essa é a rota de invasão da exploração madeireira na Terra Indígena Awá utilizada igualmente como um "corredor de passagem".

0 fogo é atribuído a ação desses invasores na extração ilegal de madeira, mas também de fazendeiros que continuam a colocar fogo para formação de pastos nas 
antigas fazendas que possuíam antes da desintrução da área. Calculam-se mais de mil cabeças de gado pertencentes a um desses fazendeiros que retornaram após o processo judicial de demarcação e retirada dos invasores da área indígena.

Alguns dias antes da nossa chegada na área indígena Awá, a Polícia Florestal, vinda da operação na terra indígena Araribóia, apreendeu, entre as bases norte e sul da FUNAI, motoserras e motocicletas usadas pelos invasores, cinco deles levados presos para Santa Inês. Essas toras ilegalmente extraídas são vendidas pelos madeireiros. Conforme os relatos: "tão falando da Araribóia, aqui está pior (Awá)”. Na Araribóia foram tomadas providências, mas na área Awá, apesar das informações enviadas, nenhuma ação efetiva estava em curso.

Da base sul onde pernoitamos por causa de um tronco de madeira atravessado na estrada que impediu a caminhonete fretada de prosseguir até o Juriti, aguardando o quadriciclo do posto indígena para visitar a aldeia, podia ser visto o fogo se alastrar por todo perímetro da reserva indígena, inclusive nas encostas da Serra da Desordem, no braço dela que começa no Tiracambu e na continuidade até a Serra Azul, em proporções nunca antes vistas, segundo comentários. Após a remoção do tronco com motosserra pudemos seguir viagem.

A visão geral a partir da Base Sul e no trecho até a aldeia Juriti, assim como os depoimentos ouvidos, traça um quadro no qual grande parte da reserva estava destruída pelo fogo. No contexto dessa visita, o assunto prevalente era sobre o "tamanho da devastação incontrolável do fogo”. Mas os focos do incêndio dentro da reserva indígena são igualmente resultado da formação de pastos para o criatório de gado. Inclusive, contaram que duas índias guajajara es- tavam alugando pasto para fazendeiro em São João do Caru. 0 fazendeiro, segundo disseram, quando perguntado sobre a utilização da reserva como pasto, afirmara: "olha, nós estamos aqui autorizados pelas indias guajajaras”. Por isso, justificam ter “jogado o gado" dentro da reserva Awá.

Os integrantes do Batalhão da Polícia Florestal vindos da reserva Araribóia, segundo nos disseram durante o pernoite na Base Sul, haviam comentado que a "invasão (na terra indígena Awá) está pior que na Araribóia”. Ao prenderem cinco invasores encontrados na estrada a partir de Maranata, no estreito da reserva, voltaram a Santa Inês à espera de uma ordem de serviço da FUNAI para retornar à área.

A invasão madeireira é mais intensa na área norte da reserva onde ficava a agropecuária Alto do Turiaçu e um antigo povoado de Vitória da Conquista. Todos estavam desolados com o fogo lastreando nas encostas da Serra da Desordem. Esse fogo nos seguiu durante toda viagem e atingia tanto a vegetação rasteira quanto o interior da mata.

\subsection{Relatos dos Awá}

$\mathrm{Na}$ aldeia Juriti, conversamos com os Awá que lá se encontravam e também com o grupo que estava no local próximo ao antigo povoado do Caju, há $8 \mathrm{~km}$ da aldeia, para colher mandioca e fazer farinha. Alguns deles na aldeia se preparavam para encontrar com um terceiro grupo que estava no cocal - ua - do Água Preta para extração de mel. Na opinião de Pirahima'a, o cocal estava muito reduzido, só tinha mesmo tucum. Nessas ocasiões, costumam caçar, mas hoje utilizam espingardas porque, conforme dizem, não têm mais tempo para elaborar arcos e flechas das palmeiras e gramíneas lá encontradas. Segundo o depoimento: 
0 pessoal tem que tirar mandioca. E então precisamos ir para o mato e voltar ligeiro para fazer farinha, senão a família vai passar fome. Também pegamos a caça lá no mato: jabuti, cobra, jararaca. Nós comemos de tudo: sucuri, papacai (que é a curica), caçamos e trazemos para cá e ainda plantamos mandioca para não passar fome. Às vezes enterramos a caça no chão, que funciona igual uma geladeira.

Ao ser perguntado se as onças que rondam a área não acham essa caça, respondeu: "Não, botamos fogo em cima, para onça não achar. Assim ela não sente o cheiro. Fica um cheiro que ela não conhece”. 0 fogo utilizado pelos Awá para o cozimento dos alimentos e despistamento da caça armazenada é muito diferente desse fogo destruidor que ora se alastra pela mata.

Além de comparar o processo de enterramento da caça com uma geladeira, nosso interlocutor chamou atenção para que os Awá salvam todos os filhotes desses bichos que caçam. "Nós pegamos os filhotes, não matamos não. Damos para as mulheres criarem”. Na cultura Awá, “as relações de troca estabelecidas entre humanos e não humanos é o que permite a construção de um coletivo ou a composição de um mundo comum" (LATOUR, 2004, p. 23).

No grupo que estava no roçado de mandioca fazendo farinha, Wyrohó comentou sobre o fogo que rodeava o acampamento das famílias, dizendo: "até aquela matinha pegou fogo. Foi tudo. Não ficou uma folha. Muito pau caído”.

Após meu retorno, fui informada que outro foco de fogo criminoso posto por um grupo de invasores entre a Base Sul e a aldeia Juriti ultrapassou o igarapé Água Preta chegando muito próximo da aldeia Juriti e do posto indígena. Desse modo, os cinco quilômetros livres do fogo que atravessamos de quadriciclo, até o perímetro dessa aldeia, já estava igualmente consumido pelas chamas.

As práticas culturais de caça e coleta dos Awá e atualmente da agricultura - "para não morrer de fome" - é o que possibilita a "composição de um mundo comum" diametralmente contrário daquela que se faz fora de qualquer "procedimento regrado" pela destruição da floresta como resultado das intenções e ações humanas. Assim, os Awá, desenvolvem "princípios de organização que agrupam em uma só ordem humanos e não humanos como um só coletivo" (LATOUR, 2004, p. 82).

\section{Considerações finais}

Esse relatório antropológico deve ser lido não só como parte de uma constatação de incidente sobre a natureza, nem só como parte das conversas e interlocuções estabelecidas em campo, mas como registro de resultados que, em suas formas objetivas e objetificadas, se apresentam para nossa análise na vistoria realizada por solicitação do Ministério Público Federal.

Os obstáculos encontrados à visita à área, inclusive mediante negativas iniciais à entrada na terra indígena Awá sem que a Coordenação Geral de Índios Isolados e Recém Contatados (CGIIRC) da FUNAI viesse a disponibilizar algum veículo de tração para o deslocamento e chegada na aldeia Juriti; assim como a evidência da destruição da mata e vegetação secundária pelo fogo imposto com toda força de atualidade durante a visita a Terra Indígena Awá, tomada como objeto de análise, permitem um distanciamento e estranhamento crítico em relação à indisposição dos agentes do Estado responsáveis pelas decisões administrativas a en- 
frentar os conflitos, a garantir a segurança e permanência do povo indígena em toda área homologada diante da ação de madeireiros, fazendeiros e invasores que promovem práticas com o objetivo de descaracterização territorial da área indígena Awá.

Nesse caso, como diz o antropólogo Tim Ingold (2012, p. 29):

A moral da história (...) é que problemas inicialmente pequenos - se nós tivermos medo de reconhecê-los ou de falar o seu nome por medo de infringir as normas da conduta racional - podem crescer até o ponto em que a vida social ordinária não possa ser sustentada.

Nessa perspectiva, parafraseando livremente o antropólogo Didier Fassin (2010), trata-se também de reconhecer um direito territorial e cultural, além de toda obrigação legal, e trata-se também de reconhecer um direito territorial e cultural, além de toda obrigação legal, e logo um sujeito, os Awá, além de todo assujeitamento, no que constitui igualmente a razão humanitária.

Por fim, os Awá-Guajá que vivem na pré-amazônia maranhense possuem condições de existência consideradas contrastivas à "modernidade", situadas à margem das representações de "desenvolvimento" e "progresso" dos poderes econômicos e políticos hegemônicos. As situações de conflitos socioambientais, experienciadas por esse grupo indígena, são indicativas de um processo de territorialização produzido pela pressão de interesses econômicos, conjugados às políticas desenvolvimentistas executadas por programas de governo. Trata-se de novo tipo de genocídio doméstico, no qual se incluem formas de genocídio cultural, perpetradas contra grupos de caçadores e coletores ameaçados de extinção, como os Awá-Guajá, vítimas de uma economia de desenvolvimento predatório.

Todavia, povos tradicionais como os Awá-Guajá, até então definidos de modo prevalente como "às margens da história", têm, na contemporaneidade, seus direitos culturais e territoriais reconhecidos como legítimos. Paradoxalmente, encontram-se sujeitos a atos de submissão resultantes, atualmente, da implementação de políticas definidas como desenvolvimentistas, que reconfiguram novas práticas de governança como forma de controle sobre tais povos e populações defınidos como tradicionais. Dessa forma, o desenvolvimento tem sido concebido como fonte de salvação da economia, da política e do Estado-Nação. Em sendo assim, o sofrimento que, por acaso seja infligido a tais povos e populações é considerado, pelos poderes constituídos, em parte justificável e a oposição a esses processos é vista como uma resistência ao futuro e uma perspectiva arraigada ao passado. No entanto, a resistência protagonizada nas margens tem configurado novas formas de fazer história, que se realizam na centralidade das práticas e concepções do Estado de Direito.

\section{Referências}

BALLÉ, W. L. Footprints of the Forest. USA: Columbia University Press, 1994.

BALLÉ, W. 0 povo da capoeira velha: caçadorescoletores das terras baixas da América do Sul. In: Conferência Amazônica da Fundação Memorial da América Latina. São Paulo, 1992.

BENSA, A. Da micro-história a uma antropologia crítica. In: REVEL, J. (Org.). Jogos de Escala: a experiência da microanálise. Rio de Janeiro: Editora Fundação Getúlio Vargas, 1998.

CLIFFORD, J. Itinerarios Transculturales. Barcelona: Gedisa, 1999. 
CORMIER, L. A. Kinship with Monkeys: the Guajá foragers of eastern Amazônia. New York: Columbia University Press, 2003.

CORNIER, L. A. Um aroma no ar: a ecologia histórica das plantas anti-fantasma entre os Guajá da Amazônia. Mana, v. 11, n. 1, Rio de Janeiro, p. 129-154, 2005.

FASSIN, D. La raison humanitaire. Une histoire morale du temps présent. Paris: Hautes Études/ Seuil, 2010.

INGOLD, T. Caminhando com dragões em direção ao lado selvagem. In: STEIL, C. A.; CARVALHO, I. C. de M. (Orgs.). Cultura, percepção e ambiente. Diálogos com Tim Ingold. Porto Alegre: Terceiro Nome, 2012. p. 15-30.

KUPER, L. International Protection against Genocide in Plural Societies. In: David Maybury-Lewis (Org.). The prospects of plural society. Washington: American Ethnological Society, 1982. p. 207219.

LATOUR, B. Políticas da natureza. Como fazer ciência na democracia. Santa Catarina: EDUSC, 2004.

O'DWYER, E. C. Laudo Antropológico. Processo judicial no ${ }^{\circ}$ 5.353-8. 5a Vara da Justiça Federal do Maranhão. 2001.

RIBEIRO, D. Diários Índios: os Urubus-Kaapor. São Paulo: Companhia das Letras, 1996.

STEIL, C. A.; CARVALHO, I. C. de M. Diferentes aportes no âmbito da Antropologia fenomenológica: diálogos de Tim Ingold. In: STEIL, C. A.; CARVALHO, I. C. de M. (Orgs.). Cultura, percepção e ambiente. Diálogos com Tim Ingold. Porto Alegre: Terceiro Nome, 2012. p. 31-48. 
RESUMO

Os Awá-Guajá que vivem na pré-amazônia maranhense possuem condições de existência consideradas contrastivas à "modernidade", situadas à margem das representações de "desenvolvimento" e "progresso" dos poderes econômicos e políticos hegemônicos. As situações de conflitos socioambientais, experienciada por esse grupo indígena, são indicativas de um processo de territorialização produzido pela pressão de interesses econômicos, conjugados às políticas desenvolvimentistas executadas por programas de governo. Tratase de novo tipo de genocídio doméstico, no qual se incluem formas de genocídio cultural, perpetradas contra grupos de caçadores e coletores ameaçados de extinção, como os Awá-Guajá, vítimas de uma economia de desenvolvimento predatório.

\section{PALAVRAS-CHAVE}

Terras indígenas. Conflitos socioambientais. Awá-Guajá.

\section{ABSTRACT}

The Awá-Guajá living in Maranhão preAmazon live under conditions considered contrastive to "modernity" at the margins "development" and "progress" representations to the hegemonic economic and political powers. The situations of socioenvironmental conflicts experienced by this indigenous group indicates a process of "territorilization" produced by the pressure of economic interests, combined with development policies implemented by government programs. This is a new type of domestic genocide, which include forms of cultural genocide perpetrated against groups of hunters and gatherers threatened with extinction, such as the Awá-Guajá, victims of a predatory development economy.

\section{KEYWORDS}

Indigenous Lands. Socio-environmental conflicts. Awa-Guajá. 
